\begin{tabular}{|c|c|c|}
\hline$\bigcup_{\text {INESEG }}$ & $\begin{array}{l}\text { INTERNATIONAL } \\
\text { ENGINEERING, } \\
\text { SCIENCE AND } \\
\text { EDUCATION } \\
\text { GROUP }\end{array}$ & 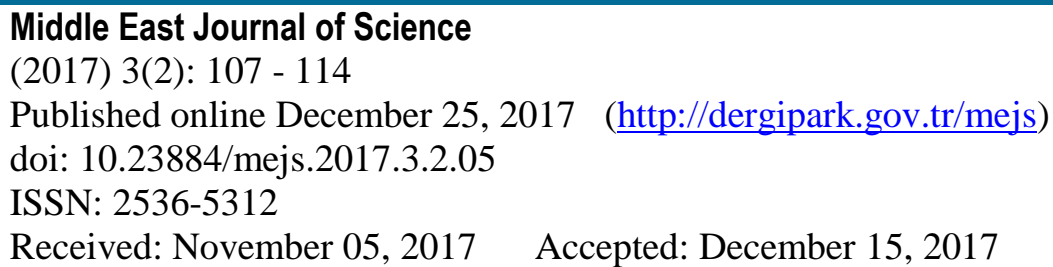 \\
\hline
\end{tabular}

\title{
WATER ABSORPTION AND BIODEGRADATION PROPERTIES OF POTATO WASTE- BASED POLYURETHANE FOAMS
}

\section{Tülay GÜRSOY ${ }^{* 1}$, M.Hakkı ALMA ${ }^{2}$}

${ }^{* 1}$ Van Yuzunci Yil University, Faculty of Science, Department Of Chemistry, 65080 Van/TURKEY

${ }^{2}$ Sütçü Imam University, Faculty of Forestry, Department of Industrial Forestry, 46.100 K.Maras / TURKEY

*Corresponding author: tulaygursoy@yyu.edu.tr

\begin{abstract}
Potato-based polyurethane foams(PUFs) were prepared from the liquefied potato waste-based polyols. Potato wastes liquefied in the presence of polyethylene glycol/glycerin-dominant liquefaction reagent by using sulphuric acid as catalyst in a microwave oven system under stirring. $350 \mathrm{watt} / \mathrm{min}$ as microwave energy, $300 \mathrm{rpm} / \mathrm{min}$ as mixing speed and mass ratio as Biomass/PEG400/Glycerol 5/12/3 w/w/w had been constanted. The liquefied potato waste-based polyols were characterized for the preparation of polyurethane foams. The potato-based polyol which was obtained from $9 \%$ sulfuric acid catalyst within 30 min liquefaction reaction period was chosen for the preparation of $P U$ foams. Biodegradation and water absorption properties of $P U$ foams were measured and contrasted with syntetic petroleum-based commercial foams. Biodegrability of PU foam-based on liquefied potato wastes-contained foams was determined according to service biodegradation test for three months. The mean amount of water absorption of potato wastes-based PU foams was measured within 1, 2, 4, 8, 12, 24 and 48 hour. The weight losses of the liquefied potato wastesbased foams along with commercial synthetic PU-type rigid foams had been found $17.84 \%$ and $0,107 \%$ respectively. The mean amount water intake at potato wastesbased PU foams were higher within seven different time period than synthetic foams. Biodegradation and water absorption properties were found to be higher than those of petroleum-based PU foams dependently biomass content.
\end{abstract}

Key words: Potato waste, liquefaction, polyurethane foam, biodegradation, water-absorption 


\section{Introduction}

Polyurethane (PU) is one of the most useful three-dimensional polymers, since it can exist in various forms of sheets, adhesives and paints. Polyurethanes can be produced through the interaction between polyols and polyisocyanate in polyaddition-type polymerization reaction (Alma et. al, 2003).

Polyols (polyether and polyester) and isocyanate are the two main raw materials for PU foam (PUF) production and currently are obtained from the fossil resources (Pan et. al,2011). The major drawback of petroleum-based products is that they are non-renewable and not-biodegradable (Pan et. al, 2011).

The preparation of low-cost polyols from abundant and renewable biomass resources has long been an interesting subject in the polyurethane industry (Yao et. al,1996). Liquefying biomass to produce the industrial chemicals is a novel method to utilize biomass resource. Earlier researches on this area were started from the liquefaction of wood mill (Besteu et. al,1985; Maldas and Shiraishi,1997;Vuori and Niemela,1988;Yamada and Ono,1999). However, most of the reaction are rigor and consume lots of energy. Researches improved the reaction conditions and the liquefaction product was able to be used to produce the resin or foam (Wang and Chen, 2007; Alma et.al, 2003;Lin et. al,1994;Yao et. al,1993). The methods and principles of liquefying the wood mill gave some idea on the utilization of the agricultural straw which had the similar composition as the wood mill (Wang, 2013). In addition, some scientific studies were reported on the liquefaction of the agricultural wastes (Cineli et. al, 2013; Wang and Chen, 2007;Alma et. al,2003;Lin et. al, 1994;Yao et. al,1993;Wang,2013;Hakim et. al,2011).

According to the Turkish Statistical Institute report, 4,750 million tone potato in Turkey and 376,45 million tone in the world were cultured in 2016 (agricultural wastes based on potato (potato crust and potato vines)) almost are burned or (potato crust) were carried out in soil for decaying. This condition pollutes the environment and wastes the biomass resource.

Granola strain potato contain mainly $84,62 \%$ water and $15,37 \%$ solid substances. Solid substance components are $11,80 \%$ starch, $0,78 \%$ invert sugar, $0,77 \%$ saccharose, $0,80 \%$ cellulose and other parts about protein and phenolic matters (Didin et. al, 2000).

The research is based on the production of rigid PU foam derived from starch-contained potato waste, which is environmentally-friendly pathway and has good water-absorptive and biodegrability property to reduce the demand for non-renewable fossil fuels and to restrain production of carbon dioxide "greenhouse gas" to lower global warning.

\section{Methods}

Potato waste were cut and dried under atmospheric pressure. Potato meal (0-80 mesh) was dried in an oven at $103 \pm 2^{\circ} \mathrm{C}$ for 24 hours before re-use. The liquefaction reagent was a mixture of PEG\#400 and glycerin. Sulfuric acid was used as catalyst. Liquefaction reaction of biomass was realized by microwave-assistant heating method. The normal heating program was used, which was at $350 \mathrm{watt} / \mathrm{min}$ with $300 \mathrm{rpm} / \mathrm{min}$ mixing speed. An equivalent amount of sodium hydroxide aqueous solution (40\% w/w) was added to neutralize the acid catalyst, thus the liquefied potato waste-based polyols were obtained. The specific gravity, apparent viscosity and surface tension of the liquefied potato-based 
polyols were measured according to ASTM 4669, ASTM D 4878 and Pendant Drop Method respectively. Measurements were conducted at $25 \pm 2{ }^{\circ} \mathrm{C}$. The acid and hydroxide number of the biomass-based polyol were also determined by the titration method according to ASTM D 4662-08 and ASTM D 4274-05 individually.

\section{Preparation of the Rigid Foams}

The $\mathrm{pH}$ of the potato crust-based polyol obtained above was adjusted by adding $40 \mathrm{wt} \%$ sodium hydroxide aqueous solution as blowing agent. Thus, the definite amounts of liquefied potato crust-based polyol, catalyst, surfactant (polymer editor) and water premixed thoroughly in a plastic cup in first step polymerization. Then, the prescript amount of MDI (at an isocyanate index of 90) was added and mixed quickly at a high stirring speed of $8.000 \mathrm{rpm}$ for 15-20 seconds in second step polymerization. It was allowed to rise freely at room conditions. Foams were allowed to cure at room temperature for two days and then were removed from the plastic cup before cutting into test samples.

Table 1. Foam Formulations for the Liquefied Potato Wastes-Based Polyols.

\begin{tabular}{|c|c|c|}
\hline & Ingredients & $\begin{array}{l}\text { Parts by } \\
\text { Weight }\end{array}$ \\
\hline \multirow{5}{*}{$\begin{array}{c}1 . \\
\text { Liquid }\end{array}$} & Potato-based polyol & 100 \\
\hline & Catalyst & 3 \\
\hline & Surfactant & 2.5 \\
\hline & $\begin{array}{l}\text { Blowing agent (water, including water from neutralization with } \mathrm{NaOH} \\
\text { solution) }\end{array}$ & 6.25 \\
\hline & PEG 400 (Polyethylene Glycol 400) & 20 \\
\hline $\begin{array}{c}2 . \\
\text { Liquid }\end{array}$ & MDI (Diphenylmenthanediisocyanate) & 130 \\
\hline
\end{tabular}

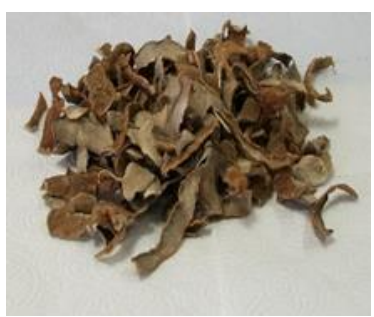

Potato

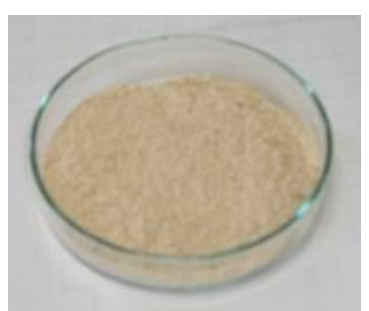

Potato miles

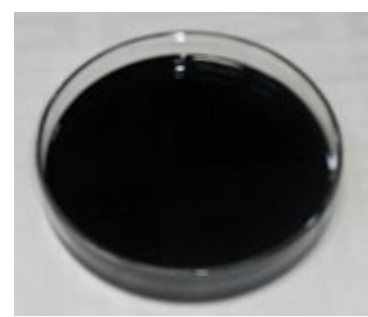

Liquefied potato

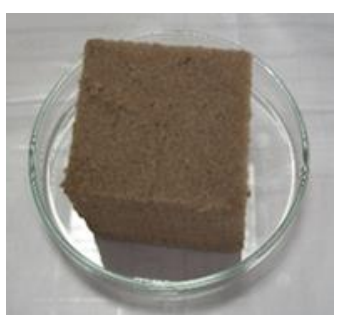

Potato-based foam

Fig. 1. Photographs of potato waste, potato miles, potato-based polyol and polyurethane foam derived from potato.

\section{Biodegradation of Potato-based PU Foams}

Biodegrability of potato waste-based PU foams and synthetic foams were evaluated according to service test. Oven-dried foam blocks $(1 \mathrm{~cm} \mathrm{x} 1 \mathrm{~cm} \mathrm{x} 1 \mathrm{~cm})$ were buried in culture soil. $\left(\mathrm{CaCO}_{3}: 20.35 \%\right.$, Salinity: 0.52 mhos/cm, pH: 7.96, organic matter: 49\%, Total nitrogen: 0.13\%, Phosphorous: 30.4 ppm, Exchangable $\mathrm{K}^{+}$ions: $1,56 \mathrm{~m} . \mathrm{e} / 100 \mathrm{~g}$ soil and Exchangable $\mathrm{Mg}^{+2}$ ions: $6.96 \mathrm{~m} . \mathrm{e} / 100 \mathrm{~g}$ ) then incubated 
at $25^{\circ} \mathrm{C}$ for 3 months. Water contents of soil was maintained at $60 \%$ by occasional addition of water. At the end of the incubation period, impurities on the samples were completely removed and oven dried. Eventually, the percent weight loss was calculated by the conventional method (Alma et al.2003).

\section{Water Intake Test of PU Foam Based on Liquefied Potato}

Prepared PU foam was cut into small pieces of equal volume (10 mm x $10 \mathrm{~mm} \times 10 \mathrm{~mm}$ ) before water intake test. The mean amount of water absorption of potato waste-based PU foams and petroleumbased foams were measured within 1, 2, 4, 8, 12, 24 and 48 hour according to following equation:

Water absorption $=\frac{W_{S}-W_{0}}{W_{0}} \times 100$

where $W_{0}$ is the original weight of the PUF $(\mathrm{g})$ and $W_{s}$ is the weight of the PU foam after waterabsorption.

\section{Results and Findings}

Table 2. Effects of the reaction conditions on liquefaction reaction

\begin{tabular}{lccccc}
\hline Biomass & Catalyst & $\begin{array}{c}\text { acid catalyst } \\
\text { concentration } \\
\%\end{array}$ & $\begin{array}{c}\text { Reaction time } \\
(\mathrm{min})\end{array}$ & $\begin{array}{l}\text { *PIP } \\
(\%)\end{array}$ & $\begin{array}{c}\text { Reaction Completion } \\
\text { Temparature }\left({ }^{\circ} \mathrm{C}\right)\end{array}$ \\
\hline Potato & $\mathrm{H}_{2} \mathrm{SO}_{4}$ & 9 & 15 & 4.88 & 80.3 \\
Potato & $\mathrm{H}_{2} \mathrm{SO}_{4}$ & 4 & 15 & 6.04 & 78.2 \\
Potato & $\mathrm{H}_{2} \mathrm{SO}_{4}$ & 3 & 15 & 9.25 & 76.6 \\
Potato & $\mathrm{H}_{2} \mathrm{SO}_{4}$ & 9 & 30 & 0.60 & 97.0 \\
Potato & $\mathrm{H}_{2} \mathrm{SO}_{4}$ & 4 & 30 & 4.70 & 90.4 \\
Potato & $\mathrm{H}_{2} \mathrm{SO}_{4}$ & 3 & 30 & 5.74 & 84.2
\end{tabular}

Conditions: Potato waste/PEG400/Glycerin $=5 / 12 / 3,350 \mathrm{watt} / \mathrm{min}$ microwave-heating energy, $300 \mathrm{rpm} / \mathrm{min}$ mixing speed

*PIP: Percent Insoluble Part

As can be seen from Table 2, by incremental acid catalyst concentrations, the PIP and reaction completion temperature had been decreased. In addition, the flash result was obtained from liquefaction reactions is as to liquefaction reactions of starch-main componently potato waste were not a balanced reaction and re-polymerizations were not occurred all the time.

Table 3. Properties of the Liquefied Potato-Based Polyols

\begin{tabular}{lccccccc} 
Catalyst & $\begin{array}{c}\text { Organic } \\
\text { acid } \\
\text { concentration } \\
{[\%]}\end{array}$ & $\begin{array}{c}\text { Reaction } \\
\text { Time } \\
{[\mathrm{min}]}\end{array}$ & $\begin{array}{c}\text { Apparent } \\
\text { Density } \\
{\left[\mathrm{g} / \mathrm{cm}^{3}\right]^{\mathrm{a}}}\end{array}$ & $\begin{array}{c}\mathrm{Viscosity}^{\mathrm{V}} \\
{[\mathrm{Cp}]^{\mathrm{a}}}\end{array}$ & $\begin{array}{c}\text { Surface } \\
\text { Tension } \\
{[\mathrm{dyn}} \\
/ \mathrm{cm}]^{\mathrm{a}}\end{array}$ & $\begin{array}{c}\text { Acid } \\
\text { Value } \\
{[\mathrm{mg}} \\
\mathrm{KOH} / \mathrm{g}]\end{array}$ & $\begin{array}{c}\text { Hydroxyl } \\
\text { Value } \\
{[\mathrm{mgH}}\end{array}$ \\
\hline $\mathrm{H}_{2} \mathrm{SO}_{4}$ & 3 & 15 & 1.317 & 586 & 218.7 & 38.92 & 412.00 \\
$\mathrm{H}_{2} \mathrm{SO}_{4}$ & 4 & 15 & 1.337 & 589 & 223.7 & 40.03 & 388.03 \\
$\mathrm{H}_{2} \mathrm{SO}_{4}$ & 9 & 15 & 1.348 & 744 & 347.6 & 43.75 & 385.82 \\
$\mathrm{H}_{2} \mathrm{SO}_{4}$ & 3 & 30 & 1.158 & 877 & 193.9 & 33.41 & 407.90
\end{tabular}




$\begin{array}{llllllll}\mathrm{H}_{2} \mathrm{SO}_{4} & 4 & 30 & 1.212 & 880 & 199.5 & 43.68 & 381.75 \\ \mathrm{H}_{2} \mathrm{SO}_{4} & 9 & 30 & 1.257 & 893 & 334.2 & 50.31 & 372.49\end{array}$

${ }^{a}$ Polyols don't contain residue.

Potato waste polyols did not contain a residue component therefore values of specific gravity, viscosity and surface tension increased with increscent liquefaction ratio.

Generally, the viscosity of the liquefied mixtures obtained by microwave assistant liquefaction was slightly higher than the fossil-based polyol due to biomass components remaining in the liquefied mixture. These values listed in the Table 3 were somewhat larger but were still suitable for the preparation of polyurethane foam.

From the Table 3, the most significant change is the hydroxyl value (about three quarter of the mixture of PEG400 and glycerin). Table 3 showed that the hydroxyl value of the liquefied mixture had decreased and acidic substances had been produced with increasing liquefaction time (Pu and Shiraishi, 1994). These results suggested that dehydration and/or oxidation reactions occurred during the liquefaction of potato crust (Yao et al., 1996).

\section{Biodegradation of Potato-based PU Foams}

The weight losses (resulted from a 3-month service biodegradation test) of the liquefied potato-based foams along with commercial synthetic PU-type rigid foams are $17.84 \%$ and $0,107 \%$, respectively. This can be explained by the fact that potato waste-based foams contain much more natural components as starch and cellulose (Alma et al., 2002;Ge and Sakai, 1993; Chen and Lu, 2009).
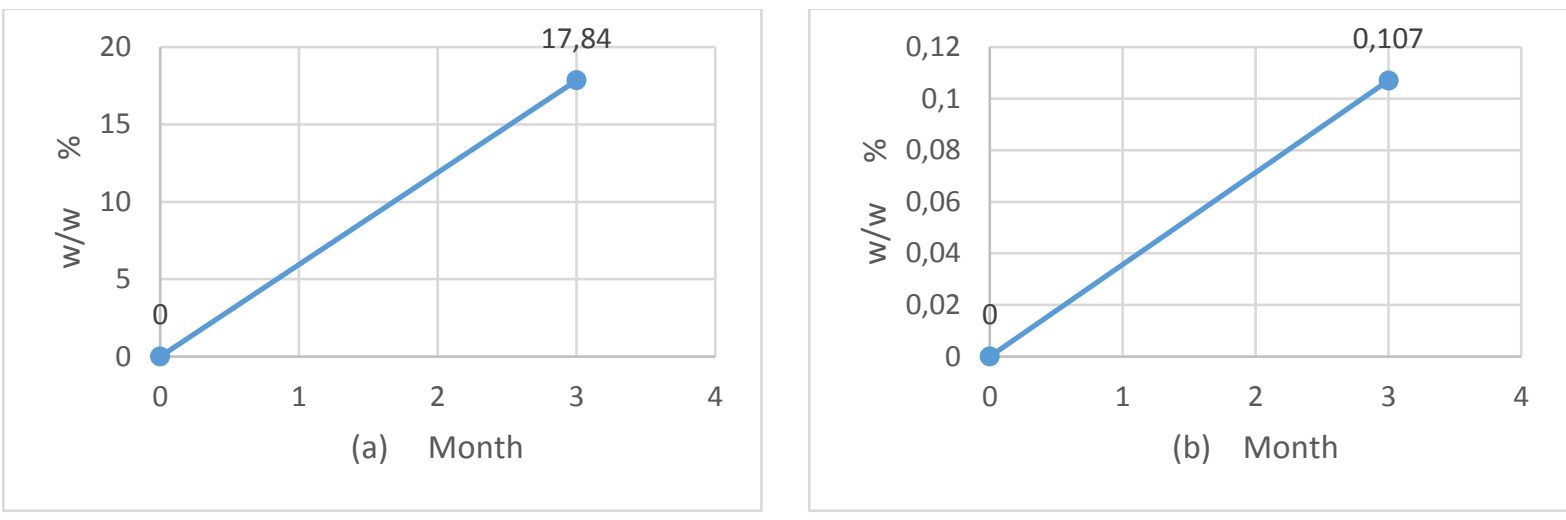

Fig.2 Biodegradation Test Results of (a)Potato PU foam and (b)Synthetic PU foam

\section{Water Intake Test For Potato-based Foams}

The mean amount water intake at potato waste-based PU foams were 137\%, 156\%, 226\%, $249 \%, 393 \%, 608 \%, 1,030 \%$ within 1, 2, 4, 8, 12, 24, and 48 hour respectively. The mean amount of water intake at petroleum-based foams were as to $35 \%, 42 \%, 52 \%, 65 \%, 76 \%, 84 \%$, and $89 \%$ within $1,2,4,8,12,24,48$ hour. This situation can be explained by the excellent hydrophilic characteristic properties of potato structure. Hydrophilic or water-absorbing foams are useful in manufacturing 
absorbent products or in agricultural or horticultural purposes (Alfani et. al, 1998; Perkins, 1992; Hostettler, 1980).
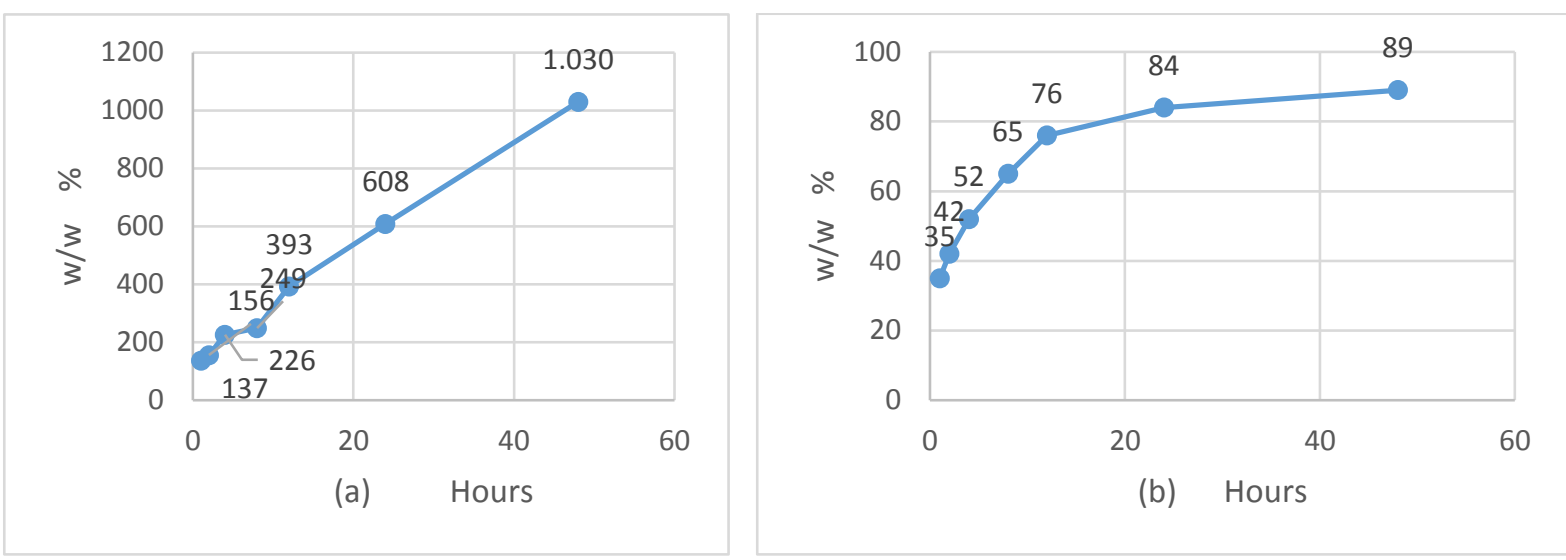

Fig.3 Water Intake Results of (a)Potato PU foam and (b)Synthetic PU foam

\section{Conclusion}

In this study, potato meal was liquefied with PEG\#400 main solvent and glycerin excipient solvent about $99.4 \%$ in mild conditions. This phenomenon was related to the high functionality of starches. During the liquefaction, starch and miserable cellulose degraded. Catalyst concentration, liquefaction time affected the liquefaction of potato meal-based polyols and their characteristics. Characteristic properties of biomass-based polyol were similar and slightly much over those of petroleum polyols.

1. Polyols showed to be good candidates for being used in PU foam synthesis.

2. Potato meal-based PU foams have greater biological degradability than synthetic fossils-based PU foams.

3. Water absorption of PU foams were found to be higher than synthetic foams.

Due to the concerns over the depletion of petroleum resources, there must been extensive interests to develop bio-based polyols and PUs (Luo et al., 2013; Gu et al., 2013; Zhang et al., 2014)

\section{Recommendations}

As a novel technology, liquefaction of potato components has still many issues and further efforts are required for practical applications.

\section{Acknowledgement}

This investigation was financially supported by Van Yuzuncu Yil University Scientific Search Project Department with No: FBE-D060 project. The authors are grateful for this. 


\section{References}

[1] Alfani, R., Iannace, S., Nicolais, L., 1998. Synthesis and characterization of starch-based polyurethane foams. Journal of Appl. Polym. Sci. 68:773-780.

[2] Alma, M. H., Baştürk, M. A., Dığrak, M., 2002. Liquefaction of agricultural biomass wastes with polyhydric alcohols and its application to polyurethane-type foams. 12 th European Conference on Biomass for Energy, Industry and Climate Protection, 17-22 Haziran 2002, Amsterdam, 1247-1250.

[3] Alma, M. H., Baştürk, M. A., Dığrak, M., 2003. New polyurethane-type rigid foams from liquefied wood powders. Journal of Materials Science Letter, 22: 1225-1228.

[4] Alma, M.H., Yoshioka, M., Yao, Y., Shiraishi, N.,(2004). Effects of phosphoric acid on liquefaction of wood and optimum liquefaction processing parameters. Wood Sci.Technol. 30: 39-47.

[5] Alma, M. H., Baştürk, M. A., Dığrak, M., 2003. New polyurethane-type rigid foams from liquefied wood powders. Journal of Materials Science Letter, 22: 1225-1228.

[6] Besteu, L., Soyer, N., Bruneau., C. Brault, A., 1965. Wood liquefaction with hydrogen and helium in the presence of iron additives. The Canadian Journal of Chemical Engeenering, 64:775-780.

[7] Chen, F., Lu, Z., 2009. Liquefaction of wheat straw and preparation of rigid polyurethane foam from the liquefaction products. Journal of Applied Polymer Science, 111: 508-516.

[8] Cinelli, P., Anguillesi, I., Lazzei, A., (2013). Green synthesis of flexible polyurethane foams from liqufied lignin. European Polymer Journal, 49:1174-1184.

[9] Didin, M.\& Fenercioğlu, H., 1999. Nevşehir-Niğde yöresinde yetiştirilen farklı patates çeşitlerinin bazı fiziksel ve kimyasal özelliklerinin belirlenmesi üzerinde bir araştırma, II. Ulusal Patates Kongresi Bildirileri, 28-30 Haziran 1999, Erzurum. s.273-283.

[10] Ge, J. J., Sakai, K., 1993. Compressive properties and biodegradabilities of polyurethane foams derived from condensed tannin. Mokuzai Gakkaishi, 39(7): 801-806.

[11] Gu, R., Sain, M.M., Konar, S.K., 2013. A feasibility study of polyurethane composite foam with added hardwood pulp. Ind. Crop. Prod. 27:33-38.

[12] Hakim, A. A. A., Nassar, M., Emam, A., Sultan, M., 2011. Preparation and characterization of rigid polyurethane foam prepared fro sugar-cane bagasse polyol. Material Chemistry and Physics, 129: 301307.

[13] Hapburn, C., (1991). Polyurethane Elastomers, Elsevier Press, Oxford, 1.

[14] Hostettler, F., (1980) Polyurethane Foams. U.S. Pat. 4, 197, 372 (1980) (Patent)

[15] Lin, L. Z., Yoshiokam, M., Yao, Y. G., Shiraishi, N., 1994. Liquefaction of wood in the presence of phenol using phosphoric acid as a catalyst and the flow properties of the liquefied wood. J. Appl. Polym. Sci., 52(11): 1629-1636.

[16] Luo, X., Mohanty, A., Misra, M., 2013. Lignin as a reactive reinforcing filler for water-blown rigid biofoam composites from soy oil-based polyurethan. Ind.Crop. Prod. 47:13-19. 
[17] Maldas, D.\& Shiraishi, N., 1997. Liquefaction of biomass in the presence of phenol and $\mathrm{H}_{2} \mathrm{O}$ using alkalies and salts as the catalyst. Biomass Bioenergy, 12: 273-279.

[18] Pan, H., Zheng, Z., Chung, Y. H., (2011). Microwave-assisted liquefaction of wood with polyhydric alcohols and its application in preparation of polyurethane (PU) foams. J. Wood Prod., 70(4): 461-670.

[19] Perkins, N.B.,(1992), CrossRef.14. U.S. Pat. 5, 116, 550.(Patent)

[20] Pu, S., and Shiraishi N. (1994). "Liquefaction of wood without a catalyst IV.”. Mokuzai Gakkaishi $40(8), 824-829$.

[21] Szycher, M., (1999). Szycher's Handbook of Polyurethanes. First Edition. Ph. D. CRC Press, New York, 34.

[22] Vuori, A.\& Niemela, N., 1988. Liquefaction of kraft lignin II-reaction with a homogenous lewis acid catalyst under mild temperature conditions. Holzfoschung, 42: 327-330.

[23] Yamada, T.\& Ona, T., 1999. Rapid liquefaction of lignocellulosic waste by using ethylene carbonate. Bioresource Technol., 70(1): 61.

[24] Yao, Y., Yoshioka, M., Shiraishi, N., 1996. Water absorbing polyurethane foams from liquefied starch. J. Appl. Polym. Sci. 60:1939-1949.

[25] Yao, Y., Yoshioka, M., Shiraishi, N., 1993. Combined liquefaction of wood and starch in a polyethylene glycol / glycerin blended solvent. Mokuzai Gakkaishi, 39: 930-938.

[26] Yao, Y. Yoshioka, M., Shiraishi, N. (1996). "Water absorbing polyurethane foams from liquefied starch”, J. Appl Polym Sci 60: 1939-1949.

[27] Wang, H.\& Chen, H. Z., (2007). A novel method of utilizing the biomass resource: Rapid liquefaction of wheat straw and preparation of biodegradable polyurethane foam. Journal of other Chinese Institute of Chemical Engeneers, 38: 95-102.

[28] Wang, M., Zhang, X., Zhang, W., Tian, D., Lu, C., 2013. Thermoplastics of polyurethane composites prepared from mechanochemically activated waste cotton fabric and reclaimed polyurethane foam. Journal of Applied Polym. Sci., 128(6): 3555-3563.

[29] Zhang, L., Zhang, M., Hu, L., Zhou, Y., 2014. Synthesis of rigid polyurethane foams with castoroil based flame retardant polyols. Ind. Crop. Prod., 52:380-388. 